\title{
MAKNA TEOLOGI PERAYAAN NATAL YESUS KRISTUS
}

\author{
Marselino Cristian Runturambi \\ Pemuda GMIM \\ Sion Sentrum Sendangan Wilayah Kawangkoan Satu \\ runturambimarcelino@gmail.com
}

\begin{abstract}
This study aims to look how Christians understand the meaning of Christmas, how leader effort or church institutions in teaching this concept to the congregation, as well as internal and external factors that influence the congregation's understanding of the concept. This research is using qualitative research methods with a descriptive approach. the data that gathered in this research are using documentation, observation and interview techniques.
\end{abstract}

From the results of the analysis and discussion / interpretation, indications are obtained that: (1) the understanding members of GMIM Sion Sentrum Sendangan regarding Christmas is still lacking. (2) the role of church leaders in teaching Christmas is still inadequate. (3) internal factors that influence the understanding of the congregation in understanding the meaning of Christmas is the lack of enthusiasm to find out a deep understanding of Christmas while the external factor is the lack of learning from church leaders in depth about Christmas.

The recommendation of this study is that the church have a specific and in-depth teaching about the meaning of Christmas, so it can make it easier to teach this concept, and can be a motivation for the congregation to know a deep understanding of the meaning of Christmas.

Keywords: The meaning of Christmas, Christmas Celebration of Jesus Christ, Christmas Symbols

ABSTRAK: Tujuan penelitian ini adalah untuk mencari bagaimana pemahaman umat kristen tentang Makna Natal, bagaimana upaya dari pimpinan atau lembaga gereja dalam mengajarkan konsep ini kepada anggota jemaat, serta faktor internal dan eksternal yang mempengaruhi pemahaman jemaat tentang konsep tersebut. Penelitian ini menggunakan metode penelitian kualitatif dengan pendekatan deskriptif. Data dikumpulkan melalui teknik dokumentasi, observasi dan wawancara.

Dari hasil analisis dan pembahasan/interpretasi, maka diperoleh indikasi bahwa: (1) pemahaman dari anggota jemaat GMIM Sion Sentrum Sendangan mengenai Natal masih kurang. (2) peran para pimpinan gereja dalam mengajarkan Natal masih belum memadai. (3) faktor internal yang mempengaruhi pemahaman anggota jemaat dalam memahami makna natal adalah kurangnya semangat untuk mencari tahu pemahaman yang mendalam tentang natal sedangkan faktor eksternal yakni kurangnya pembelajaran dari pimpinan gereja yang mendalam tentang Natal. 
Dari hasil temuan tersebut maka direkomendasikan agar gereja mempunyai pengajaran yang khusus dan mendalam tentang makna natal, sehingga dapat memudahkan untuk mengajarkan konsep ini, dan dapat menjadi motivasi bagi anggota jemaat untuk mengetahui pemahaman yang mendalam mengenai makna natal.

\section{Kata Kunci: Makna Natal, perayaan Natal Yesus Kristus, Simbol-simbol Natal}

\section{PENDAHULUAN}

Keberadaan kehidupan umat manusia pada dasarnya tidak pernah lepas dari tingkah laku sosialnya sehingga sikap saling ketergantungan antara satu dengan yang lainnya merupakan hal yang wajar atau manusiawi itulah mengapa manusia sering disebut mahkluk sosial. Keadaan sosial tersebut secara perlahan mulai menghasilkan sebuah pola hidup yang pada akhirnya membentuk sebuah tradisi atau adat-istiadat yang diwariskan dari generasi ke generasi, ${ }^{57}$ baik secara intelektual, materialis, maupun yang bersifat kebatinan sebagai reaksi dalam suatu tatanan kehidupan bermasyarakat. $^{58}$ Warisan ini juga secara langsung turut mempengaruhi kehidupan beragama, tak terkecuali agama Kristen. Bahkan dalam kekristenan warisan atau tradisi dianggap sebagai salah satu sarana untuk dapat memahami makna yang terkandung dalam Alkitab atau jembatan memperdalam, merefleksikan serta mengimplementasikan keimanan. ${ }^{59}$

Orientasi kehidupan beragama tidak pernah lepas dari pemujaan dan ucapan

\footnotetext{
57 H. Richard Niebuhr, Kristus dan Kebudayaan, (Jakarta, Petra Jaya, 1949), h. 37

58 Rahmat Subagya, Kepercayaan dan Agama, (Yogyakarta: Kanisius, 1993), hh. 13-14.

59 Henri Veldhuis, Kutahu yang Kupercaya, (Jakarta: BPK Gunung Mulia, 2010), hh. 306-307.
}

syukur sebagai representasi dan aktualisasi lembaga keagamaan. ${ }^{60}$ Keadaan ini tergambar jelas dengan adanya perayaan pada hari-hari khusus yang senantiasa diperingati setiap tahun yang terus menerus dilestarikan dan dikembangkan di setiap agama. Dalam kekristenan pun terdapat begitu banyak hari besar gerejawi yang tak henti-hentinya mewarnai kehidupan keberagamaanya dan terus diperingati dalam setiap generasi ke generasi lainnya. Salah satu perayaan yang terus dilestarikan adalah perayaan penyambutan kelahiran sang Mesias Yesus Kristus yaitu perayaan Natal.

Natal dirayakan oleh umat Kristen untuk memperingati akan kasih karunia Allah yang luar biasa dalam kehidupan umat manusia. Merayakan natal adalah tindakan rasa syukur atas karya Yesus Kristus yang telah datang ke dalam dunia untuk menyelamatkan manusia dari kebinasaan.

Di era milenial ini, dampak modernisme juga turut berperan melahirkan kesangsian dan penolakan atas keyakinan kekristenan, baik secara teoretis maupun secara keseluruhannya dan membatasi relevansinya pada wilayah pribadi sehingga berdampak pada implementasi perayaan-

60 Giovanni Martinetti, Mengapa Percaya, (Ende: Nusa Indah, 1998), h. 18. 
perayaan keagamaan, ${ }^{61}$ termasuk Natal. Perkembangan pemikiran ilmiah yang semakin kompleks serta memiliki kecenderungan kearah naturalistik (kembali ke tatanan nilai alamiah) turut berperan memberikan dorongan terhadap munculnya asumsi, bahwa perayaan Natal tidaklah lebih dari antek atau konspirasi kapitalisme, sehingga harus dijauhkan dan bahkan ditolak. Pemahaman ini muncul dan menyeruak seiring semakin maraknya persaingan bisnis menjelang perayaan Natal yang di dalamnya tidak bisa lepas dan berbasis pada ekonomi, sebagai contoh hadirnya tokoh Santa Claus, hadiah natal, pohon natal dan lain-lain. Itulah mengapa banyak yang mengklaim bahwa Natal hanyalah dalih yang bersifat rohani sebagai pembenaran. Padahal pada hakikatnya pelaksanaan Natal adalah lambang dari budaya konsumtif sebagaimana budaya zaman yang semakin hedonis. ${ }^{62}$

Sehingga hal ini tidak satupun memiliki konsepsi yang sama dengan kekristenan yakni menyangkut pemujaan terhadap hari kelahiran Tuhan (Inkarnasi) sehingga secara tidak langsung turut mendiskreditkan atau menganggap pemahaman tentang Natal sebagai sebuah kekeliruan. ${ }^{63}$

Persoalan mengenai objek sentral pemujaan dalam perayaan Natal dan implementasi ajaran yang benar sesuai

61 David Ray Griffin, Tuhan dan Agama Dalam Dunia PostModern, (Yogyakarta: Kanisius, 2005), h. 8.

${ }^{62}$ Harry Blamires, The Post-Christian Mind, (Surabaya: Momentum, 2003), hh. 6-7.

63 Ahmad Muhli Junaidi, Guru Menulis Himpunan Opini, (Jakarta Utara: CV. Pustaka Tunggal, 2017), h. 45. dengan kitab suci terus menerobos dari berbagai aspek. Sehingga secara tersirat dapat dikatakan bahwa pemahaman-pemahaman umat kristiani mengenai hari Natal masih bersifat intuisi tanpa adanya penalaran.

Begitu pun yang terjadi pada jemaat GMIM Sion Sentrum Sendangan, dimana banyak dari anggota jemaat yang tidak mengerti atau kurang memahami akan makna atau alasan mengapa perayaan Natal harus senantiasa diperingati dan bagaimana seharusnya mereka mengapresiasi perayaan Natal itu sendiri.

Melihat keadaan ini penulis mengamati bahwa anggota jemaat merayakan atau memperingati hari Natal belum mempunyai niat yang memadai untuk mencari tahu alasan-alasan tersebut, baik secara teologis maupun historis. Sehingga jemaat merayakan hari Natal hanya seremonial semata saja dengan mengikuti perkembangan zaman yang ada. Adapun dari tatanan para Pendeta, Guru Agama, Penatua dan Diaken/Syamas juga dijumpai tidak ada semangat dan upaya untuk mengajarkan anggotanya mengenai Natal itu sendiri. Atas dasar inilah penulis tertarik meneliti bagaimana Makna Teologi Perayaan Natal Yesus Kristus.

\section{METODE}

Penelitian yang digunakan adalah penelitian kualitatif dengan pendekatan deskriptif. Dalam konteks ilmu sosial, kegiatan penelitian diawali dengan adanya minat untuk mengkaji secara mendalam 
terhadap munculnya fenomena tertentu. ${ }^{64}$ Sebagai langkah awal dalam mengkaji fenomena yang ada, maka pada kesempatan ini, penulis menggunakan metode penelitian kualitatif dalam memperoleh data lapangan, dimana untuk mendapati makna tidak dengan melakukan generalisasi tetapi lebih menekankan pada informasi, sehingga bisa sampai pada tingkat makna.

Penelitian kualitatif menunjuk bahwa penelitian ini memang terjadi secara alamiah, apa adanya, dalam situasi normal dan tidak dimanipulasi keadaan atau kondisinya, serta menekankan pada deskripsi secara alami. Dengan sifatnya ini, penulis dituntun secara langsung di lapangan, ${ }^{65}$ yakni di jemaat GMIM Sion Sentrum Sendangan yang menjadi tempat penelitian. Sebab penelitian kualitatif adalah penelitian yang bersifat interpretif (menggunakan penafsiran) yang melibatkan banyak metode, dalam penelaan masalah penelitiannya. ${ }^{66}$ Sedangkan pendekatan kualitatif merupakan suatu pendekatan primer yang menggunakan paradigma pengetahuan berdasarkan pandangan konstruktif seperti makna jamak dari pengalaman individu, makna yang secara sosial dan historis dibangun dengan maksud mengembangkan suatu teori atau pola. ${ }^{67}$

64 Burhan Bungin, Metodologi Penelitian Kualitatif, (Jakarta: Rajawali Pers, 2011) h. 75.

65 Arikuno Suharsimi, Prosedur Penelitian Suatu Pendekatan Praktik, (Jakarta: Rineka Cipta, 2006), h. 12.

66 Dedy Solatun, Metode Penelitian Komunikasi, (Bandung: Remaja Rosdakarya, 2008), h. 5.

67 Emzir, Metode Penelitian Pendidikan Kuantitatif dan Kualitatif, (Jakarta: Rajawali Pers, 2011), h. 28.
Dalam penelitian ini, proses pengumpulan data yang dilakukan peneliti terakumalasi dari beberapa teknik. Antara lain sebagai berikut: penelitian kepustakaan yang dapat menjadi landasan dasar dan alat utama bagi pelaksanaan penelitian lapangan. ${ }^{68}$ Penelitian kepustakaan dilaksanakan dengan cara pengumpulan data dan informasi berasal dari dokumen-dokumen, buku-buku, majalah, jurnal dan catatan-catatan atau berbagai literatur maupun referensi yang berkaitan dengan Natal. Hal ini dilakukan dengan tujuan, agar supaya pandangan-pandangan yang sudah ada, bisa menjadi acuan dasar dalam penelitian yang telah dilakukan. Kemudian melalui observasi (Pengamatan) dan wawancara, dimana menggunakan teknik observasi cara yang paling efektif adalah melengkapinya dengan format atau belangko pengamatan sebagai instrumen, format yang disusun berisi item-item tentang kejadian atau tingkah laku yang digambarkan terjadi. ${ }^{69}$ Adapun dalam observasi ini dilakukan pengamatan-pengamatan yang terjadi dalam anggota jemaat, penulis berpartisipasi langsung dan berperan serta dalam kegiatan pengamatan sekaligus mewawancarai anggota jemaat. Keikutsertaan penulis bertujuan untuk mengamati lebih dalam agar mendapati data yang sebenarnya. Selain observasi dan wawancara penulis juga menggunakan dokumentasi untuk pengumpulan data. Dokumen merupakan catatan peristiwa yang sudah berlalu dan dideskripsikan dalam

68 Mardalis, Metode Penelitian, (Jakarta: Bumi Aksara, 2009), h. 28.

69 Arikunto Suharsimi, Prosedur Penelitian Suatu Pendekatan Praktik, (Jakarta: Rineka Cipta, 2006), h. 229. 
bentuk tulisan serta gambar. ${ }^{70}$ Dalam hal ini penulis mengkaji catatan-catatan atau dokumen gereja kemudian menghubungkannya dengan masalah yang telah ditulis.

\section{KAJIAN PUSTAKA}

\section{Pengertian Natal}

Secara etimologi kata Natal berasal dari bahasa Latin Dies Natalis yang artinya Hari Lahir. Pengertian natal pada umumnya bagi umat Kristiani berarti penyambutan Sang Juruselamat yaitu Yesus Kristus yang lahir ke dunia. Dahulu juga dipakai istilah MelayuArab Maulid atau Milad. Pada negara-negara yang berbahasa Arab, hari raya ini disebut dengan Idul Milad. Dalam bahasa Inggris Natal disebut Christmas yang artinya Mass of Christ atau disingkat Christ-Mass, diartikan sebagai hari untuk merayakan kelahiran Yesus. Kata Christmas berasal dari Gereja Katolik Roma, kata tersebut telah banyak dieja pada periode yang berbeda. Berikut adalah bentuk-bentuk usang yang ditemukan dalam tulisan-tulisan Inggris kuno: Crystmasse, Cristmes, Cristmas, Crestenmes, Crestenmasr Cructurees, Cristynmes, Crismas, Kyrsomas, Xtemas, Cristes-messe, Cristemasse, Crystenmas, Crystynmas, Chrystmas, Chrystemes, Chrystemasse, Chrystymesse, Cristenmas, Christen Mas, Christmass, Christmes, semuanya ini mengartikan sebagai "Misa Kristus", yaitu

70 Sugiyono, Memahami Penelitian Kualitatif, (Bandung: Alfabeta, 2007),h. 82. pengulangan peringatan penebusan tubuh Kristus dan darah Yesus. ${ }^{71}$

Christmas biasa pula ditulis X'mas, suatu penyingkatan yang cocok dengan tradisi Kristen, karena huruf "X" dalam bahasa Yunani merupakan singkatan dari Kristus atau dalam bahasa Yunani Chi-Rho. Akan tetapi, ada beberapa orang yang tidak setuju dengan kata ini, karena menurut mereka X'mas itu adalah salah satu penghujatan kepada Yesus, dan juga kata ini dibuat oleh orang-orang yang tidak percaya pada Yesus Kristus (Jesus Christ) sehingga kata "Christ" pada Christmas mereka ganti dengan kata " $X$ " karena mereka tidak ingin mengucapkan nama Yesus. Menurut Patricia dan Stewart ini adalah miskonsepsi umum yang menyatakan bahwa kata X'mas berasal dari upaya kaum sekuler untuk menghilangkan tradisi keagamaan dari Natal dengan membuang kata Christ dari Christmas, namun penggunaannya sudah ada sejak abad $k e-16 .{ }^{72}$

Adapun menurut Kamus Besar Bahasa Indonesia, Natal adalah kelahiran seseorang atau kelahiran Isa Almasih (Yesus Kristus). Jadi, Natal itu adalah perayaan untuk memperingati akan hadirnya Allah yang menjelma menjadi manusia.

\section{Tinjauan Teologis}

Mengacu dari pengertian mengenai Natal yang dipahami oleh orang-orang

${ }^{71}$ W. F. Dawson, Christmas: Its Origin And Associatoins, (New York: Public Library, 1992), h. 9.

72 O'Conner, Patricia T.; Kellerman, Stewart, Origins of the Specious: Myths and Misconceptions of the English Language. (New York: Random House, 2009), h. 77. 
Kristen, yaitu peringatan tentang kelahiran Yesus, maka dalam Alkitab terdapat cerita tentang Kelahiran Yesus yang ditulis dalam Injil Perjanjian Baru yakni pada kitab Matius 1:18-2:23 dan Lukas 2:1-21. Dalam kedua cerita dalam kitab ini tidak mempunyai paralel tetapi mempunyai waktu yang berkesinambungan mengenai kelahiran Yesus. ${ }^{73}$ Masing-masing menceritakan kejadian yang sama dengan sudut pandang yang berbeda. Injil Matius dari sudut pandang Rasul Matius yang adalah seorang pemungut pajak menceritakan perihal kedatangan orang majus yang mencari dan menyembah "raja" yang baru lahir, serta mempersembahkan hadiah yang mahal-mahal. Sedangkan Injil Lukas dari sudut pandang Lukas yang adalah seorang dokter menceritakan kisah ini dengan lebih detail, termasuk adanya malaikat dan kedatangan gembala domba yang menyembah bayi Yesus di palungan, secara lebih kronologis. Injil Lukas tidak menuliskan mengenai orang-orang majus dari Timur, tetapi menceritakan tentang kelahiran Yohanes Pembaptis yang terjadi sekitar 6 bulan sebelum kelahiran Yesus, termasuk wujud dari penampakan malaikat Gabriel yang menyampaikan terlebih dahulu kepada Zakharia, ayah Yohanes Pembaptis. ${ }^{74}$

Akan tetapi, pada bagian ini penulis hendak memfokuskan peristiwa kelahiran Yesus Kristus yang ditulis dalam kitab Matius, dimana Matius menempatkan berita kelahiran Yesus setelah terlebih dahulu

73 Millard J. Erickson, Teologi Kristen Volume Dua, (Malang: Gandum Mas, 2012), hh. 398399

74 John Drane. Introducing the New Testament. Memahami Perjanjian Baru: Pengantar historis-teologis, (Jakarta: Gunung Mulia, 2005), h. 55 menuliskan tentang silsilah Yesus, sementara Lukas menempatkan berita kelahiran Yesus setelah Yohanes Pembaptis. Matius ingin memperkenalkan Yesus sebagai Mesias, Anak Allah sesuai dengan nubuatan dalam Perjanjian Lama. Karena itu, ia menyebutnya sebagai anak Daud dan anak Abraham. ${ }^{75}$ Ia ingin membuktikan dan memperkenalkan Yesus melalui kelahiran-Nya yang ajaib, kelahiran Yesus bukan merupakan kelahiran biasa melainkan karena mujizat dan intervensi Allah. Disebut sebagai mujizat karena kelahiran Yesus bukan berasal dari hubungan seksual antara Yusuf dan Maria, melainkan oleh karena pekerjaan Allah melalui intervensi oleh Roh Kudus.

\section{Maria mengetahui dari seorang} malaikat bahwa dia telah mengandung dari Roh Kudus tanpa persetubuhan. Setelah itu dia dan suaminya Yusuf meninggalkan rumah mereka di Nazaret untuk berjalan ke kota Betlehem untuk mendaftar dalam sensus yang diperintahkan oleh Agustus, Kaisar Romawi pada saat itu. Karena mereka tidak mendapat tempat untuk menginap di kota itu, bayi Yesus dibaringkan di sebuah palungan (malaf) Kelahiran Kristus di Betlehem Efrata, Yudea, di kampung halaman Daud, nenek moyang Yusuf, memenuhi nubuat nabi Mikha (Mikha 5:1-2). Di Israel purba mereka mengenal ada dua kota Betlehem, kota Betlehem satunya lagi berada di tanah Zebulon. ${ }^{76}$ Hal ini juga dinubuatkan dalam kitab Yesaya yang secara pribadi telah

75 Yusak B. Hermawan, My New Testament. (Yogyakarta: Andi, 2010) hh. 39-40

76 Jaerock Lee, Pesan Salib, terjemahan Esther K. Chung, (Seoul Korea: Urim Books, 2007) h. 24. 
membahasnya dalam Pasal 11:1 dan meskipun tidak membahas secara gamblang mengenai Nazaret. Kata Nazaret dalam Perjanjian Baru kemudian selalu dihubungkan dengan Yesus, sehingga bukanlah hal yang mustahil bahwa nubuatan tersebut memang mengarahkan nubuatan tersebut kepada Yesus. Dengan demikian, gelar orang Nazaret bagi Yesus bukan hanya sekadar gelar yang menunjukan alamat asal Yesus, tetapi justru lebih luas bahkan menjangkau nubuatan Yesaya dalam Perjanjian Lama. ${ }^{77}$

Ada kemungkinan pada waktu Matius mencatat mengenai kelahiran Yesus, karena sudah mendengar tuduhan-tuduhan atas orang-orang Yahudi, menjadi hal wajar ketika orang-orang Yahudi menyebarkan berita bahwa Maria melahirkan tanpa ada hubungan biologis dengan Yusuf. Karena kaum Yahudi sangat sensitif mengenai perilaku-perilaku yang menyimpang dan sangat menjaga akan kekudusan. Oleh karena itu, ketika Yusuf mengetahui bahwa tunangannya hamil, namun ia belum mengetahui bahwa Maria hamil dari Roh Kudus, maka posisi Yusuf pada saat itu sangat sulit, untuk itu ia bermaksud akan menceraikan Maria secara diam-diam. ${ }^{78}$ Akan tetapi, dalam sebuah mimpi Yusuf ada sebuah penampakan dari Malaikat utusan Allah, dan memberitahukan mengenai pengandungan Yesus dari seorang perawan oleh Roh Kudus dan memusatkan perhatian kepada nama Mesias. Itulah pesan

77 Geoffrey. W. Bromiley, The New International Standard Bible Encyclopedia: Volume Two, (Michigan: William B. Eerdmans Publishing Company, 2015), hh. 806-807.

78 J.J. de Heer. Tafsiran Alkitab Injil Matius Pasal 1-22, (Jakarta: BPK Gunung Mulia, 2000), hh. 15-16.
Malaikat kepada Yusuf. $^{79}$ Sehingga hal ini membuat Yusuf mempertimbangkan akan rencananya untuk menceraikan Maria, mungkin hal ini juga mempengaruhi rasa tulus dan kencintaannya kepada Maria, oleh karena itu, maka Penulis Matius menempatkan Yusuf sebagai orang yang istimewa karena keadilan, kebijaksanaan dan kebaikan hatinya. ${ }^{80}$ Atas dasar inilah sehingga pesan yang disampaikan oleh malaikat dalam mimpinya diterimanya yang menenteramkan kekhawatirannya.

Kemudian beralih ke kedatangan orang-orang majus dari Timur yang diduga adalah Arabia atau Persia untuk melihat Yesus yang baru dilahirkan. Orang-orang bijak tersebut mula-mula tiba di Yerusalem dan melaporkan kepada raja Yudea, Herodes Agung, bahwa mereka telah melihat sebuah bintang yang sekarang disebut Bintang Betlehem menyambut kelahiran Seorang Raja. Selanjutnya Bintang tersebut memandu mereka ke Betlehem Yudea di tempat penginapan Maria dan Yusuf. Mereka mempersembahkan emas, kemenyan, dan mur kepada bayi Yesus. Ada tiga kekayaan dalam hikmat tentang orang Majus itu: 1) Pengarang Injil Matius menganggap kedatangan orang Majus itu sebagai pertanda bahwa di dalam Kristus nubuat-nubuat Perjanjian Lama digenapi. Di Mazmur 72:10 dikatakan bahwa bangsa-bangsa asing akan membawa upeti dan persembahan kepada Raja Mesias. Dan lihatlah, waktu Yesus masih kecil bangsa

79 Dianne Bergant \& Robert J. Karris. Tafsir Alkitab Perjanjian Baru, (Yogyakarta: Kanisius, 2002), h. 35

${ }^{80}$ Jack Dean Kingsbury, Injil Matius Sebagai Cerita "Berkenalan Dengan Narasi Salah satu Injil", (Jakarta: BPK Gunung Mulia, 2004), hh. 60-61. 
asing benar membawa persembahan kepada Dia. 2) Disamping itu Matius ingin memperlihatkan bahwa bangsa asing mendahului orang Yahudi. Orang Yahudi gempar, tetapi mereka tinggal di Yerusalem, padahal orang asing pergi ke Betlehem. Hal itu menjadi suatu pendahuluan bagi seluruh sejarah gereja, di mana orang kafir lebih rela untuk menerima Kristus daripada orang Yahudi. 3) Sebagai hal yang ketiga dapat disebutkan bahwa orang Majus dengan mempersembahkan hadiah-hadiah mengajarkan kepada bahwa mengakui Kristus sebagai Raja, harus disertai dengan kerelaan untuk berkorban bagi Dia. ${ }^{81}$

Ketika bermalam, orang-orang majus itu mendapatkan mimpi yang berisi peringatan bahwa Raja Herodes merencanakan pembunuhan terhadap anak tersebut. Karena itu mereka memutuskan untuk langsung pulang tanpa memberitahu Herodes suksesnya misi mereka. Matius kemudian melaporkan bahwa keluarga Yesus mengungsi ke Mesir untuk menghindari tindakan Raja Herodes yang memutuskan untuk membunuh semua anak di bawah dua tahun di Betlehem untuk menghilangkan saingan terhadap kekuasaannya. Setelah kematian Herodes, Yesus dan keluarga kembali dari Mesir, tetapi untuk menghindar dari raja Yudea baru (anak Herodes Agung, yakni Herodes Arkhelaus) mereka pergi ke Galilea dan tinggal di Nazaret.

81 J.J. de Heer. Tafsiran Alkitab Injil Matius Pasal 1-22, h. 27.

\section{Sejarah Natal}

Para murid Yesus dan orang-orang Kristen yang hidup pada abad pertama, tidak pernah sekalipun mereka merayakan Natal sebagai hari kelahiran Yesus pada tanggal 25 Desember. Dalam Alkitab, tidak ditemukan walau satu ayatpun Tuhan Allah maupun Yesus yang memerintahkan untuk merayakan Natal, ${ }^{82}$ sebab perayaan setiap tanggal 25 Desember, adalah perayaan agama Paganis (penyembah berhala) yang dilestarikan oleh umat Kristiani. Akibat dari sinkristime atau mungkin dimaksudkan untuk menentang peringatan hari lahirnya Dewa Matahari dalam agama Romawi Kuno serta untuk menyatakan bahwa Yesus Kristuslah sang Matahari kebenaran, sehingga penetapan hari Natal atau peringatan tentang kelahiran Yesus ditetapkan pada 25 Desember. ${ }^{83}$

Namun di sebelah Timur orang telah sejak dahulu memikirkan mukjizat pemunculan Allah dalam rupa manusia. Menurut tulisan-tulisan lama suatu sekte Kristen di Mesir telah merayakan pesta Epifani (Yunani: epiphaneia) yang berarti perwujudan atau penyataan ilahi, tetapi kemudian menjadi ta epiphania yang dipakai untuk arti pesta. Perayaan gerejawi ini atau Epifani adalah perayaan gereja Timur yang merujuk pada kelahiran Yesus sekurangkurangnya pada abad ke 4, yang dirayakan pada tanggal 6 Januari. $^{84}$ Tetapi yang dimaksudkan oleh sekte ini dengan perayaan

${ }^{82}$ Yusuf Eko Basuki, Rayakan Natal Setiap Hari, (_Garudhawaca, 2013), h. 5.

83 Dr. F.D Wellem, Kamus Sejarah Gereja, (Jakarta: BPK Gunung Mulia, 2006), h. 159.

${ }^{84}$ Gerald O. Collins \& Edward G. Farrugia, Kamus Teologi, (Yogyakarta, Kanisius, 1996), h. 70. 
pesta Epifania ialah ditandai oleh beberapa hal, yang berkaitan dengan permulaan penyataan karya Yesus Kristus yang menyatakan Allah. Yesus sebagai Anak Allah-yaitu pada waktu Ia dibaptis di sungai Yordan dan bahkan mujizat yang Yesus buat di Kana yang di Galilea, sebagai tandatandaNya dan dengan itu Ia menyatakan kemuliaanNya dan murid-muridNya percaya kepada-Nya. Tema umum semua peristiwa ini adalah Yesus Kristus menyatakan Allah kepada manusia. ${ }^{85}$

Gereja sebagai keseluruhan bukan saja menganggap baptisan Yesus sebagai Epifania, tetapi terutama kelahiran-Nya di dunia. Perayaan kedua pesta ini berlangsung pada tanggal 5 Januari malam (menjelang tanggal 6 Januari) dengan suatu tata ibadah yang indah, yang terdiri dari Pembacaan Alkitab dan puji pujian. Ephraim dari Syria menganggap Epifania sebagai pesta yang paling indah. Ia katakan: "Malam perayaan Epifania ialah malam yang membawa damai sejahtera dalam dunia. Siapakah yang mau tidur pada malam, ketika seluruh dunia sedang berjaga jaga?" Pada malam perayaan Epifania, semua gedung gereja dihiasi dengan karangan bunga. Pesta ini khususnya dirayakan dengan gembira di gua Betlehem, tempat Yesus dilahirkan. Sesuai dengan anggapan ini, Gereja Timur merayakan pesta Epifania pada tanggal 6 Januari sebagai pesta kelahiran dan pesta baptisan Yesus. ${ }^{86}$

Perayaan Natal baru masuk dalam ajaran Gereja pada abad ke-4 M. Peringatan

${ }^{85}$ James F. White, Pengantar Ibadah Kristen, (Jakarta, BPK Gunung Mulia), h. 51.

86 F.D. Wellem, Kamus Sejarah Gereja, (Jakarta, BPK Gunung Mulia, 2006), h. 96. ini berasal dari kebiasaan-kebiasaan atau tradisi upacara adat masyarakat penyembah berhala, dimana pada abad ke-1 sampai abad ke-4 M dunia masih dikuasai oleh imperium Romawi yang paganis politheisme. Orangorang Romawi merayakan tanggal 25 Desember sebagai hari kelahiran Dewa Matahari, ini adalah masa keemasan kebebasan universal dan kesetaraan untuk menghormati Dewa Matahari yang tak terkalahkan Natalis Solis Invicti (Kelahiran Sol Yang Tak Terkalahkan) ${ }^{87}$

Ketika Konstantin dan rakyat Romawi menjadi penganut agama Katolik, mereka tidak mampu meninggalkan adat atau budaya pagannya. Apalagi terhadap pesta rakyat sebagai sebuah tradisi untuk memperingati Sunday (Hari Matahari) yaitu kelahiran Dewa Matahari. Agar supaya Gereja bisa diterima dalam kehidupan masyarakat Romawi kala itu, diadakanlah sinkretisme (perpaduan agama dan budaya) dengan cara menyatukan perayaan kelahiran Sun of God (Dewa Matahari) dengan kelahiran Son of $\operatorname{God}\left(\right.$ Anak Tuhan $=$ Yesus Kristus) ${ }^{88}$

Maka pada konsili tahun $325 \mathrm{M}$ untuk mengakui doktrin resmi agama Kristen yaitu Trinitas sebagai konsep Tuhan yang benar (fakta juga bahwa orang-orang pagan Romawi inilah yang kemudian ketika Kaisar Konstantin), maka diputuskan dan ditetapkan

${ }^{87}$ Christian Ratsch \& Claudia Muller Ebeling, Pagan Christmas. The Plants, Spirit, and Rituals at the Origins of Yuletide, (Rochester, Vermont: Inner Traditions, 2006), h. 14

${ }^{88}$ Herbert W. Armstrong. The Plain Truth About Christmas, (California: Worldwide Church of God, 1994), h. 8. 
tanggal 25 Desember sebagai hari kelahiran Yesus. Kaisar Konstantin Agung sendiri sebagai pemimpin Konsili Nicea dianggap sebagai perwujudan dari dewa tertinggi Romawi yaitu Dewa Matahari Sesudah Kaisar Konstantin memeluk agama Katolik pada abad ke-4 Masehi, maka pada waktu yang samapun orang-orang kafir beramairamai ikut memeluk agama Katolik supaya orang-orang di Kekaisaran Romawi tidak lagi menyembah Dewa Matahari. ${ }^{89}$ Inilah hasil dari proses sinkretisme oleh Kaisar Konstantin, yaitu sinkretisme antara gereja dengan agama paganisme politheisme. Dan juga inilah salah satu taktik penyebaran agama Kristen ke Eropa agar dengan mudah diterima oleh mereka. Objek penyembahan atau perpaduan antara agama dan kebudayaan yang diserap oleh kekristenan atau bentuk peralihan pemujaan dari yang semula berobjekkan dewa matahari yang kemudian diambil alih atau dikontekstualisasikan secara teologi oleh kekristenan menjadi penghormatan kepada hari lahirnya Yesus, sehingga hari Natal untuk dewa matahari tersebut disematkan untuk Yesus, ${ }^{90}$ sehingga Yesus diberi gelar Sol Invictus baru. Cyprianus menyindir dengan ungkapan 'Oh, betapa ajaibnya: Allah Sang Penjaga, Pemelihara, dan Penyelenggara telah menjadikan hari kelahiran Dewa Matahari sebagai hari di mana Yesus harus dilahirkan'. Yohennes Krisostomus (Uskup Agung Konstantinopel, 347-407M) berkhotbah Hari, h. 6.

${ }^{89}$ Yusuf Eko Basuki, Rayakan Natal Setiap

90 Philip Schaff, History of the Christian Church, Volume III: Nicene and Post-Nicene Christianity, (USA: Grand Rapids, Christian Classic Ethereal Library, 2002), h. 233. 'mereka menyebutnya sebagai Hari Natal Yang Tak Terkalahkan'. Sejak masa itu, konsepsi Yesus lahir tanggal 25 Desember menjadi kebenaran mutlak Gereja Barat. ${ }^{91}$

Perayaan Natal ditetapkan tanggal 25 Desember yang diwariskan Gereja Barat, karena pada waktu itu menurut perhitungan, matahari tidak terus ke Selatan, tetapi kembali ke khatulistiwa dan ke Utara. Waktu itu dimengerti bahwa yang bergerak mengelilingi bumi adalah matahari. Dan kembalinya matahari dari Selatan ke khatulistiwa dan ke Utara itu dipandang sebagai kemenangan atas kegelapan, sebagai kemenangan dari cahaya matahari terhadap kegelapan. Dan Kristus, oleh kelahiran-Nya di kandang dihayati sebagai terang di dunia yang mengalahkan kegelapan. Maka kelahiran-Nya adalah kemenangan terang atas kegelapan. Dari sumber penyembah berhala dan titik pandang kontekstual, pemilihan tanggal dikaitkan dengan perayaan musim yang dikenal sebagai Natalis Solis Invicti yang memuja dewa matahari dan diperkenalkan oleh Kaisar Aurelian sekitar tahun 274 M. Serta diselenggarakan pada tanggal 25 Desember. Sehingga dirayakan Natal itu pada tanggal 25 Desember, sebagai fokus dan teologis adalah pengenapan mesianis dan inkarnasi Kristus. ${ }^{92}$

Setelah ditetapkannya perayaan Natal, maka umat Kristen selalu memperingati perayaan ini dengan memaknai akan kasih

91 Ahmad Muhli Junaidi, Guru Menulis Himpunan Opini, (Jakarta Utara: CV. Pustaka Tunggal), hh. 45-46.

92 Wilfred J. Samuel, Kristen Kharismatik. Refleksi atas Berbagai Kecenderungan PascaKharismatik, (Jakarta, BPK Gunung Mulia), h. 125. 
karunia Allah yang luar biasa kepada manusia. Mengacu pada tradisi Gereja Barat untuk merayakan Natal, harus ada persiapanpersiapan untuk menyambut kedatangan Yesus, ditandai dengan minggu-minggu Adven, bahwa empat Minggu sebelum Natal mulai dikhususkan untuk persiapan kedatangan Tuhan dan untuk kedatangan yang kedua sampai penghakiman terakhir. Makanya mereka disebut Hari Advent. Dengan dimulainya Advent tahun ajaran gereja di Barat mulai. Gereja Yunani memperhitungkan enam hari Minggu Adven, dan memulainya pada keempat belas November. Musim Adven ini dirancang untuk mewakili dan mereproduksi dalam kesadaran gereja sekaligus kerinduan dan pengharapan akan umur yang panjang sebelum Kristus. Selanjutnya semua hiburan yang ribut dan juga pernikahan dilarang selama musim ini. Itu Perikop dipilih dengan mengacu pada kebangkitan pertobatan dan keinginan setelah Penebus. $^{93}$

\section{Simbol-simbol Natal}

\section{Pohon Natal}

Sudah dijelaskan di atas, bahwa asal usul pohon Natal adalah untuk mengenang hari kelahiran Nimrod, yang selalu hadir di pohon "Evergreen" (Scara harafiah berarti tetap hijau, adalah jenis tumbuhan yang mempertahankan daun-daunnya sepanjang tahun. Di daerah beriklim sedang, daun ini tidak luruh pada waktu musim gugur. Kebanyakan tumbuhan ini berupa tumbuhan berdaun jarum seperti cemara dan pinus) yang

93 Philip Schaff, History of the Christian Church, Volume III: Nicene and Post-Nicene Christianity, h. 233. tumbuh dari sebatang kayu yang mati dan selalu meninggalkan bingkisan yang digantungkan dari ranting-ranting pohon itu. ${ }^{94}$ Akan tetapi mengikuti tradisi Barat, biasanya pohon natal itu dibuat dari pohon cemara yaitu pohon yang senantiasa menghijau sepanjang tahun meskipun pada musim kemarau. Ini yang melambangkan kelahiran Yesus yang mendatangkan harapan kekal bagi manusia. ${ }^{95}$

\section{Lilin}

Dalam masa Natal, Lilin menggambarkan atau memberikan gambaran tentang Kristus. Kristus dilambangkan sebagai terang bagi dunia yang gelap. Di dalam Alkitabpun tertulis tentang terang, di dalam Perjanjian Lama, Yesaya 9 : 1-6, "terang yang besar", sedangkan di dalam Perjanjian Baru, Yohanes 1: 1-18," terang manusia". Bukan hanya di dalam peribadahan saja, di rumah-rumah dan di toko-toko kerap di hias dengan lampu-lampu yang kelap-kelip, hal ini muncul sejak zaman patristik sebagai gambaran akan terang yang mengalahkan kegelapan. ${ }^{96}$

\section{Sinterklas/ Santa Claus}

Sosok Sinterklas adalah salah satu ikon tren dalam perayaan Natal dimana pusat perbelajaan dihiasi oleh berbagai pernakpernik sinterklas, sehingga kian kemari sosok ini mulai digunakan dalam organisasi

94 Herbert W. Armstrong. The Plain Truth About Christmas, h. 10.

95 Andar Ismail, Selamat Natal: 25 Karangan Tentang Natal, (Jakarta: BPK Gunung Mulia, 1981), h. 31.

96 Rasid Rachman, Hari Raya Liturgi, (Jakarta: BPK Gunung Mulia, 2009), h. 132. 
gerejawi, yang kononnya dipercayai sebagai pembawa hadiah bagi anak-anak karena itulah mengapa sosok sinterklas ini digunakan sebagai ajang bagi-bagi hadiah. Bentuk positif kehadiran sinterklas ini kemudian diadopsi oleh organisasi gerejawi sebagai wujud rasa kepedulian bagi sesama dalam perayaan Natal itu sendiri, bukan saja bagi kalangan anak-anak tetapi juga bagi kaum lansia dan bagi mereka yang membutuhkan pertolongan.

\section{Hadiah/ Tukar Kado}

Hadiah/tukar kado hanya pengadopsian ayat Alkitab untuk mengingatkan akan pemberian Allah yang begitu besar bagi umat manusia, yaitu Yesus Kristus. Yesus datang untuk menyelamatkan manusia dari dosa dan umat Kristen harus meresponinya dengan penghayatan bagi Allah yang mengacu juga pada para Majus.

\section{Makna Teologis Natal}

Perayaan Hari Natal yang diperingati dan dirayakan oleh umat Kristen telah menjadi tradisi yang mendunia, umat kekristenan menyikapi hal tersebut bukan hanya sekedar tradisi, melainkan memaknai akan karya keselamatan yang telah dilakukan Allah melaui Yesus Kristus, ${ }^{97}$

Kelahiran Yesus Kristus adalah seperti berikut: Pada waktu Maria, ibu-Nya bertunganan dengan Yusuf, ternyata ia mengandung dari Roh Kudus, sebelum mereka hidup sebagai suami isteri, (Matius 1:18).

${ }^{97}$ Andar Ismail, Selamat Natal: 25 Karangan Tentang Natal, (Jakarta: BPK Gunung Mulia, 1981), h. 31
Langkah awal yang dilakukan Yusuf pada waktu itu adalah sebuah kekeliruan, Yusuf hendak menceraikan Maria dengan diamdiam. Akan tetapi melalui malaikat Tuhan, Yusuf berani melangkah untuk menikahi Maria dalam keadaan mengandung, karena ia mau menundukkan dirinya kepada kedaulatan Allah dengan mengesampingkan kepentingannya. (Mat. 1:19-20). Seringkali dalam pengambilan keputusan manusia banyak yang mementingkan kehidupan dengan keinginan diri sendiri dan tidak menghargai rancangan Allah dalam kehidupan, sehingga cenderung tidak bersedia mengambil resiko yang akan terjadi dengan mengalihkan fokus hidup kepada rancangan Tuhan.

Allah yang berinkarnasi menjadi Yesus Kristus atau menjadi manusia adalah inisiatif Allah untuk memasuki dunia untuk menjangkau mereka. Dalam Matius 1:23, keberadaan Yesus dinyatakan sebagai "Imanuel yang berarti Allah menyertai kita". Ini menunjukkan keberadaan Yesus datang ke dalam dunia menjadi manusia bukanlah pribadi yang terpisah dari umat-Nya, tetapi Pribadi yang hidup bersama umat menyertai umat-Nya dan menyertai mereka di dalam kehidupan mereka. ${ }^{98}$

Selanjutnya kelahiran Yesus adalah kerendahan hati Sang Pencipta yang menjelma sebagai manusia, kelahiran Yesus juga sebagai titik awal Misi Kristus dalam dunia untuk menyelamatkan umat dari dosa. Keberadaan Yesus adalah Allah yang

98 Peniel D. Maiaweng, "Inkarnasi: Realitas Kemanusiaan Yesus”, Jurnal Teologi Jaffray. Vol. 13 Nomor 1 (Sekolah Tinggi Theologia Jaffray, 2015), hh, 102-103. 
sempurna dan Manusia yang sempurna menyatakan bahwa, sebagai manusia Ia bisa mati dan sebagai Allah Ia menjadikan kematian itu sebagai pembayaran yang cukup bagi dosa seluruh dunia. Hal ini menunjukkan bahwa keabsahan Allah datang kedunia menunjukkan bahwa Yesus adalah Juruselamat Sejati. ${ }^{99}$

Berabad-abad, perayaan ini bergerak dinamis dalam pasang surut kesadaran umat. Hanya saja, kecenderungan akhir-akhir ini tampak menjebak, yakni lumuran kemewahan atas Natal dengan alasan perayaan besar. Padahal, sejatinya kebesaran Natal tidak pernah digambarkan Alkitab dalam perayaan, melainkan dalam kerelaan Sang Juru Selamat, untuk bertemu umat (sekalipun berlansung dalam nuansa penolakan, dan tidak ada tempat yang tersedia bagi Dia). Tidak ada penyambutan, yang ada penolakan. Tidak tersedia kelayakan bagi seorang Raja, yang tersaji justru penghinaan. Tak ada gegap gempita pesat, tetapi kesyahduan malam kudus. Natal memang sering terjebak dalam sebuah makna. ${ }^{100}$

\section{HASIL DAN PEMBAHASAN}

Di lingkup Gereja Masehi Injili di Minahasa (GMIM) Jemaat Sion Sentrum Sendangan masa raya Natal dalam kegiatan ibadah disebut ibadah "Pohon Terang," yaitu peribadatan yang memperingati penyambutan Natal Yesus Kristus. Tidak ada yang tahu

\footnotetext{
${ }^{99}$ Charles C. Ryrie, Teologi Dasar: Panduan Populer untuk Memahami Kebenaran Alkitab, (Yogyakarta: Andi, 1992), h. 23.

100 Bigman Sirait, Gereja yang Membumi, (Selemba Raya: Yapama, 2015), h. 95
}

pasti mulai dari kapan tradisi ini dilakukan di Minahasa.

Tradisi ini diambil alih dari kebiasaan orang Eropa, khususnya dari tradisi bangsa Jerman, yang kemudian telah mengalami inkulturasi menjadi tradisi Kristiani yang dikaitan dengan perayaan Natal Yesus Kristus. ${ }^{101}$ Keteguhan Kristus diasosiasikan dengan pohon cemara yang adalah simbol daya hidup yang tak pernah pudar, simbol ketegaran serta keabadian, seperti halnya pohon ini tetap hijau bahkan di tengah musim dingin membeku sekali pun. Sementara semua dedauan hijau berubah menjadi coklat dan akhirnya gugur akibat suhu yang perlahan melapaui titik beku menurut peralihan musim, pohon cemara tetap hijau sepanjang waktu (evergreen).

Mulai pada tahu 1980-an di Minahasa, ibadah "Pohon Terang" mulai menjadi acara komunitas Kristen di luar gereja. Hampir setiap organisasi, perkumpulan maupun instansi yang di dalamnya ada umat Kristiani, mengadakan ibadah Pohon Terang. ${ }^{102}$

Sejak sekurangnya sepuluh hingga lima belas tahun terakhir ini ibadah Pohon Terang yang dilaksanakan di dalam wilayah pelayanan GMIM lebih cenderung disebut ibadah pra-Natal atau ibadah menyongsong Natal.

Hari Natal pada dasarnya adalah penyataan Allah yang ilahi menjelma menjadi

101 Andar Ismail, Selamat Natal: 25 Karangan Tentang Natal, (Jakarta: BPK Gunung Mulia, 1981), h. 31.

102 https://www.gmim.or.id/sedikit-mengenaimasa-raya-natal (diunduh pada tahun 2019, jam 19.21) 
manusia secara utuh untuk penebusan umat manusia yang percaya. Perayaan Natal juga adalah suatu perayaan yang menjadi arti sangat penting dalam semua maknanya bagi umat Kristiani. Hari Natal seringkali sebagai hari kehidupan pertama, pada hari Natal adalah merupakan kehidupan pertama Kristus menjadi manusia. Lahirnya Juruselamat ini sebagai hubungan manusia kepada Allah semakin dekat. Juga pada momen Natal, lebih penting bahwa kasih Allah tidak ada yang berbeda dan selalu adil setara pada semuanya.

Sehingga hal ini merupakan suatu perayaan yang sangat penting dan paling ditunggu bagi semua banyak orang. Walaupun nyatanya dalam Alkitab tidak terdapat pengajaran dari Yesus untuk merayakan atau memperingati sebuah kelahiran. Akan tetapi, melihat dari peristiwa kelahiran Yesus di Betlehem, seluruh Alam Semesta turut merayakannya kelahiran-Nya.

Dalam jemaat GMIM Sion Sentrum Sendangan ditemui pemahaman anggota jemaat atau informan mengenai Natal. F.R, M.R, S.P, A.T, C.P, M.S dan F.S mengatakan bahwa Natal itu adalah hari Kelahiran Yesus Kristus dan Natal adalah momen yang dinanti-nanti setiap tahunnya, dimana semua anggota keluarga akan berkumpul sehingga membawa damai bagi semua orang. ${ }^{103}$ F.H.R, A.M dan M.S mengatakan bahwa Natal adalah tradisi yang sudah lama ada, kemudian ditambah oleh D.J dan S.E mengatakan Natal adalah kesederhanaan merayakan hari kelahiran Yesus Kristus. Setelah itu peneliti bertanya kepada informan, kenapa umat

103 Wawancara.
Kristen harus merayakan hari Natal. ${ }^{104}$ D.J, A.T, C.P dan M.S mengatakan karena hari Natal adalah hari yang dinantikan oleh umat kristiani lewat peringatan hari lahir Yesus Kristus. ${ }^{105}$ Berikutnya F.R, M.R, S.P, S.E dan F.S mengatakan bahwa umat kristiani merayakan hari Natal karena sudah menjadi tradisi dan kebiasaan atau rutinitas yang dibawa sampai sekarang ini, ${ }^{106}$ begitupun yang dikatakan oleh K.R dan F.H.R bahwa umat kristiani merayakan hari Natal karena sudah tradisi yang dibawa dan hari Natal juga salah satu hari raya besar bagi orang Kristen. ${ }^{107}$

Sehingga sebuah pemahaman mengenai Natal dari anggota jemaat hanya sekedar pengetahuannya tanpa memikirkan atau mempelajari sebuah makna yang mendalam. Hal ini dikarenakan kegiatan-kegiatan yang dilakukan oleh gereja banyak yang terfokus pada pelaksanaan peribadatan di masingmasing kelompok dan kategorial ataupun dalam organisasi-organisasi lainnnya. Demikian juga dari kalangan jemaat tidak mempunyai minat untuk mempelajari dan memahami Natal itu sendiri, begitupun dari kalangan Pelayan Khusus yang kurang mempunyai antusias untuk mengajarkan pemahaman yang mendalam mengenai Natal kepada anggota jemaat. Sehingga pengajarannya tak melebihi dari renungan atau pesan firman yang disampaikan dalam peribadatan.

Adapun faktor-faktor internal dan eksternal yang mempengaruhi pemahaman

\footnotetext{
104 Wawancara.

105 Wawancara.

106 Wawancara.

107 Wawancara.
} 
jemaat mengenai makna Natal yakni, pengaruhnya perkembangan mordenisasi dalam kekristenan yang membuat fokus gereja bukan pada pemaknaan yang mendalam kepada jemaat, begitu pun dari jemaat yang semangatnya menyambut hari Natal, sehingga yang menjadi fokus utama hanyalah pada perayaannya dengan meninggalkan esensi dari Natal tersebut.

Memang sedikit kesulitan untuk memisahkan makna dari simbol keagamaan. Sebagian orang menganggap bahwa makna dan simbol itu satu. Kalau simbolnya diganti, maknanya pun berubah atau hilang. Tetapi orang perlu juga melihat, bahwa simbolsimbol Natal yang sudah biasa itu sebenarnya adalah hasil kreasi orang-orang Kristen tententu ditempat dan waktu tertentu. Mereka menciptakan simbol-simbol itu untuk mengungkapkan makna dan penghayatan mereka akan peristiwa Natal pada waktu itu. Bersamaan dengan itu orang juga perlu melihat, bahwa simbol-simbol itu belakangan ini ternyata juga diberi makna lain yang sangat berbeda, atau malah bertentangan dengan makna sejati kelahiran Yesus sendiri. Belum banyak orang yang mempertanyakan perubahan ini. Sebaliknya banyak diantara mereka yang menganggapnya wajar-wajar saja.

Oleh karena itu, merayakan hari Natal adalah menyikapi akan kasih karunia Allah melalui kerendahan hati dan kesederhanaan yang senantiasa dimaknai oleh umat kristiani, melalui Natal juga seharusnya mendatangkan sukacita bagi orang-orang percaya tetapi juga kepada mereka yang belum percaya. Menunjukkan solidaritas karena keberadaan
Yesus adalah manusia sejati dan hidup dalam budaya manusia. Yakni dalam Inkarnasi Yesus yang melambangkan solidaritas Yesus Kristus dengan manusia secara utuh dalam lingkup sosial budaya. ${ }^{108}$

\section{KESIMPULAN}

Pentingnya sebuah perayaan dalam kekristenan yaitu Natal untuk senantiasa diperingati dan dirayakan oleh umat kristiani, karena peristiwa kelahiran Yesus Kristus adalah suatu bentuk kasih dari Allah kepada manusia dalam upaya penyelamatan manusia dari dosa. Makna sejati peristiwa Natal tetap ada dan hidup. Masalahnya adalah bagaimana makna yang sejati itu bisa lebih menyentuh dan lebih dihayati dalam kehidupan nyata manusia sehari-hari dan sebagaimana perayaan-perayaan Natal tahunan itu bisa lebih mengungkapkan makna sejati. Tentu saja hal itu tidak cukup hanya dengan khotbah-khotbah atau renungan-renungan Natal, sehingga kadang-kadang juga hanya merupakan salah satu acara yang dianggap harus ada, meski hanya sebagai hiburan atau hegemoni semata saja karena segera setelah itu dilupakan. Karena itu ketika perayaan Natal bisa membawa orang-orang masuk ke dalam penghayatan akan makna sejati dari kelahiran Yesus, yaitu bahwa Dia-lah sebenarnya yang dinanti-nantikan oleh dunia yang belum pernah menghayati damai sejati.

108 Yakob Tomatala, Teologi Kontekstualisasi (Suatu Pengantar), (Malang: Gandum Mas, 1993), h. 22. 


\section{DAFTAR PUSTAKA}

Armstrong Herbert W. (1994). The Plain Truth About Christmas, Worldwide Church of God, California USA.

Basuki, Yusuf Eko. (2013). Rayakan Natal Setiap Hari, Jakarta, Garudhawaca.

Bergant, Dianne \& Karris Robert J. (2002). Tafsir Alkitab Perjanjian Baru, Yogyakarta, Kanisius.

Bromiley, Geoffrey. W. (2015), The New International Standard Bible Encyclopedia: Volume Two, (Michigan: William B. Eerdmans Publishing Company)

Burhan, Bungin, (2011) Metodologi Penelitian Kualitatif, Jakarta: Rajawali Pers.

BPPB (2016), Kamus Besar Bahasa Indonesia, Jakarta: Kementerian Pendidikan dan Kebudayaan Republik Indonesia.

Collins, Gerald O. \& Farrugia, Edward G. (1996), Kamus Teologi, Yogyakarta: Kanisius.

Dawson, W.F. (1992), Christmas: Its Origin And Associations, New York, Public Library.

Drane, John (2005), Introducing the New Testament. Memahami Perjanjian Baru: Pengantar historis-teologis. Jakarta: Gunung Mulia.

Emzir (2011), Metode Penelitian Kualitatif Analisis Data, Jakarta: Rajawali Pers.
, Metode Penelitian Pendidikan

Kuantitatif dan Kualitatif, Jakarta: Rajawali Pers,.

Gibbon, Edward (1781), History of The Decline and Fall of the Roman Empire, Vol. II, New York, Fred De Fau \& Company Publisher.

Griffin, David Ray (2005), Tuhan dan Agama Dalam Dunia PostModern, Yogyakarta: Kanisius.

Heer, J.J. de (2000), Tafsiran Alkitab Injil Matius Pasal 1-22, Jakarta, BPK Gunung Mulia.

Hermawan, Yusak B. (2010), My New Testament. Yogyakarta, Penerbit Andi.

Ismail, Andar (1981), Selamat Natal: 25 Karangan Tentang Natal, Jakarta: BPK Gunung Mulia.

Junaidi, Ahmad Muhli (2017), Guru Menulis Himpunan Opini, Jakarta Utara, CV. Pustaka Tunggal.

Kingsbury, Jack Dean (2004), Injil Matius Sebagai Cerita "Berkenalan Dengan Narasi Salah satu Injil", Jakarta: BPK Gunung Mulia.

Lee, Jaerock (2002), Pesan Salib, Seoul Korea, Urim Books, (Diterjemahkan oleh Dr. Esther K. Chung dalam bahasa Indonesia, 2007)

Maiaweng Peniel D. (2015), "Inkarnasi: Realitas Kemanusiaan Yesus", Jurnal Teologi Jaffray. Vol. 13 Nomor 1, Sekolah Tinggi Theologia Jaffray. 
Mardalis (2009), Metode Penelitian, Jakarta: Bumi Aksara.

Martinetti, Giovanni (1998), Mengapa Percaya, Ende: Nusa Indah.

Niebuhr, H. Richard (2007), Kristus dan Kebudayaan, Jakarta: Petra Jaya.

O'Conner, Patricia T.\& Kellerman, Stewart (2009), Origins of the Specious: Myths and Misconceptions of the English Language. New York: Random House.

Rachman, Rasid (2009), Hari Raya Liturgi, Jakarta: BPK Gunung Mulia.

Ratsch, Christian \& Ebeling, Claudia Muller (2006), Pagan Christmas. The Plants, Spirit, and Rituals at the Origins of Yuletide, Rochester, Vermont, Inner Traditions.

Ryrie, Charles C. (1992), Teologi Dasar: Panduan Populer untuk Memahami Kebenaran Alkitab, Yogyakarta: Andi.

Schaff, Philip (2002), History of the Christian Church, Volume III: Nicene and PostNicene Christianity, USA, Grand Rapids, Christian Classic Ethereal Library.
Sirait, Bigman (2015), Gereja yang Membumi, Selemba Raya: Yapama.

Solatun, Dedy (2008), Metode Penelitian Komunikasi, Bandung: Remaja Rosdakarya.

Stanilaus, Surip (2007), Rahasia di Balik Kisah Natal 1, Yogyakarta, Penerbit Kanisius.

Subagya, Rahmat (1993), Kepercayaan dan Agama, Yogyakarta: Kanisius.

Sugiyono (2007), Memahami Penelitian Kualitatif, Bandung: Alfabeta.

Suharsimi, Arikuno (2006), Prosedur Penelitian Suatu Pendekatan Praktik, Jakarta: Rineka Cipta.

Tomatala, Yakob (1993), Teologi Kontekstualisasi (Suatu Pengantar), Malang: Gandum Mas.

Veldhuis, Henri (2010), Kutahu yang Kupercaya, Jakarta: BPK Gunung Mulia.

Wellem, F.D. (2006), Kamus Sejarah Gereja, Jakarta, BPK Gunung Mulia.

White, James F. (2015), Pengantar Ibadah Kristen, Jakarta, BPK Gunung Mulia. 